\title{
A Study on Choosing Tales for Utilising as Teaching Materials in Turkish Language Education*
}

\author{
Bilge Bağc1 Ayranc1 \\ Correspondence: Bilge Bağcı Ayranc1, Bozok University, Turkey. \\ Received: October 29, 2017 \\ doi:10.11114/jets.v5i12.2738 \\ Accepted: November 26, $2017 \quad$ Online Published: November 28, 2017 \\ URL: https://doi.org/10.11114/jets.v5i12.2738
}

\begin{abstract}
Fairy tales are used intensively by Turkish teachers in Turkish lessons. Elements in tales need to be examined in many respects such as their suitability for cultural transmission, psychological benefits, and harms, correct and effective use of language and so on. The opinions of the Turkish teachers in the field are very important for this subject which needs to be examined in depth.

This research's model is descriptive, semi-structured interview is a data collection tool for this research.

Participants except one seem to have found tales interesting for all students. It is seen that teachers use talents primarily for semantic knowledge and moral values, and then for language skills achievements. Teachers have answers that they use tales more for values such as goodness, honesty, respect, and love. There may be an interpretation that teachers often do not encounter situations where students generally look askance at tales. It is seen that teachers are leading the opinion that there is not a fairy tale that should not be read. This answer is followed by the response that tales with negative contents should not be read. Ranking of tales of most positive reactions given by students can be done respectively as: all tales which have a happy ending, Keloğlan tales, Snow white tales, Aesop's Fables... According to teachers, tales which should be absolutely read by students are listed as follows: Keloğlan, Grimm Brothers, One Thousand and One Nights,..
\end{abstract}

Keywords: Turkish language education, tale, culture transfer, value teaching, skill

\section{Introduction}

\subsection{Definition of Tale}

Tales first appeared as oral literary creations. Tales are commonly used for teaching reading, listening, speaking, writing and grammar skills within the language education process. In education, it is known that tales are used as a common educational material. Before focusing on what should be taken into consideration when choosing tales as educational material, it is necessary to give general information about tales.

Tales first appeared orally and then collected and compiled into texts. As a matter of fact, it is observed that tales contain extraordinary events and usually have a happy ending (Berk, 2005: 6). Tales are often prose. There are stereotypical expressions in tales. It is a literary genre that has extraordinary events and whose place and time are uncertain. Entertaining and giving advice is intended (Çetinkaya, 2007: 9).

According to Sakaoglu (1999: 134), tale is a type of imaginary fiction in which heroes can be animals or extraordinary beings and is a type of narrative which includes place and time. According to Boratav (1995: 75), fairy tales are imaginative narratives which are prose. According to Karatay (2007: 469), tales reveal the attitude of people towards life and nature. Since tales tell the first struggles of the person with life, old motifs find a lot of place in them (Karatay, 2007: 469).

Today, it is seen that tales find place in folk literature, children's literature, adult literature. Although tales were not especially prepared for children at first, they acquired a major place in children's literature over time (Berk, 2005: 7).

\subsection{History of Tales}

There are three kinds of opinions about the history of the masters: Mythological view, histological view, and anthropological view.

${ }^{*}$ This research is extended full text of unpublished study, presented as an oral statement under EYFOR-8, 2017. 
Some of the mythological view representatives are Max Müller, Angelo de Gubertnatis, John Fiske and Sir George Cox. This view seeks foundations of tales in Vedas of Indian mythology (Günay, 1975: 17).

According to Hindu view, India is shown as a source of tales, but in this view, the tales were created in historical periods; therefore, it is claimed that the source of the tales is "Pachatantra" instead of "Veda" (Sakaoglu, 1999: 7).

According to the anthropological view, tales were created in ancient times. Those who support this view explain the reason by primitive thoughts in tales (Yardımc1, 1996: 9).

\subsection{Types of Tales}

Aarne, who made the first research on tale classifications, seperated tales into three parts (Sakaoglu, 1999: 11): 1. Animal Tales, 2. Folk Tales, 2.1. Magic Tales, 2.2. Legendary Tales, 2.3. Short Story Tales, 2.4. Stupid Giant Tales, 3. Jokes.

Yardımcı (2004: 241) makes fairy tale classification in the following way: 1. Folk Tales, 1.1. Animal Tales, 1.2. Master Tales, 1.2.1. Fantastic Tales, 1.2.2. Realistic Tales, 1.3. Allegorical Tales, 1.4. Chained Tales, 2. Literary Tales, 2.1. Processed Tales, 2.2. Produced Tales.

Folk tales are anonymous. It is seen in animal tales, which are among folk tales, lessons are given to people usually through fictional events experienced by animals. In fantastic tales, heroic rescue of people is usually handled against powerful and fantastic enemies (Yalçın \& Aytaş, 2003: 67). In realistic tales, there are fictional events that may be experienced by people in real life. For example, the issue of the punishment of Sultan for his evil is handled in these tales (Tezel, 1987: 139). In Allegorical Tales, teller narrates the events as if he experienced them (Boratav, 1995:94). In chained stories, heroes usually consist of animals, and these tales intend to entertain people instead of giving lesson.

Processed tales are written versions of folk tales by preserving their essence. (Yardımc1, 2004: 253). Produced tales reflect the imagination of the author. Their origin is based on folk tales. Produced Tales stand out by critical, adviser and artistic features (Oğuzkan, 2001: 21).

\subsection{Structure of Tales}

Tales are composed of three sections in general: 1. Rhymes Section, 2. Main Tale Section, 3. Final Section (Çetinkaya, 2007: 20; Yalçın \& Aytaş, 2002: 61).

Fantastic nature of tales also come to life through Rhymes.

Three kinds of rhymes are seen in Tales: 1. Introduction Rhymes, 2. In Tale Rhymes, 3. Tale-End Rhymes (Çetinkaya, 2007: 20).

By expressions such as "On one of these days...", it is moved to the main part in tales. This is the longest part of tale where details are told.

The last part of the tale ends again with Rhyme. To include readers, good intentions and wishes can be found in this section (Çetinkaya, 2007: 25).

\subsection{General Features of Tale}

Tales are often written in prose, and it is seen that past-time expressions are predominant in tales. In tales, it is conspicuously seen that proverbs and idioms abound. Stylistic feature of the fairy tale changes from narrator to narrator. In tales, time and space are generally ambiguous. Tales are generally anonymous. It is seen that the subject of the tales also varies. (Turkan, 2010: 19-23)

In tales, generally good-bad and just-unjust situations are told in the events. In fairy tales, it is seen that good is good, and bad is bad until the end of the tale (İşnas: 50-51).

\subsection{Place of Tales in Education}

Tales being read and listened by children caused different opinions about tale. According to those who claim that tale is harmful for children, tales have moved children away from the realities of life. Platon and Rousseau are among advocates of this idea. Against people who think like Rousseau, there are also people like Anatole France and Andre Maurois who think that tales are useful for children and they need dreams (Çetinkaya, 2007: 31-32).

Children, gains experience for life with tales. The behaviors that are tried to be given to the child are embodied with stories (Çetinkaya, 2007: 33; İşnas: 58). The child can appreciate the message in the tale by seeing the animals in tale as an instance and adding human characteristics to them (Onarıcıoğlu, 2011: 14).

Tales enrich children's imagination and empower them with creative thinking against the problems they face in life (İşnas2011: 56). In acquiring the moral and human values of the child, tales play a significant role with their contents (Karatay, 207: 470-471). Tales provide cultural and national value transfer by developing imagination, aesthetic 
pleasure, self-confidence, creativity in children (Alagöz, 2012: 36-37).

Tales contribute to the child through the educational messages they contain. The child takes tale heroes as a model and this can be appreciated as a contributing factor, too. (Karakuş, 2008: 28). Besides giving pleasure, tales have educational features in terms of heroes who become models to children (Türkan, 2010: 22).

Dilidüzgün (2003a: 10) summarizes the contributions of tale to the child in the following way:

1. The imagination of the child's world and the imaginary universe at tales are similar.

2. Exaggerations and contrasts in tales prevent the child from distracting.

3. Since tiles generally end up with positive outcomes, they give children a positive impression about the world.

4. Tales give children lessons about life.

The rich world of the tale offers a wealth of experiences for mental and linguistic development of the child. In this respect, in children's education tales should not be missing. (Kayman, 2011: 299).

\subsection{Choosing Tales for Children}

Being aware of that all tales are not written for children, in education, tales must be chosen according to their needs (Ünlüer, 2013: 154).

While choosing tales for children, formal (classical) structure tales must firstly be evaluated. General information about the book should be found on the cover, and be away from complexity. Attention should be paid to visuality, liveliness and durability of the cover. In children's books, care must be taken to ensure that the book's binding style is robust, since robustness is important in terms of use. It should be noted that dimensions of the book should be appropriate for the child's use, and the child should not have difficulty while holding the book. Paper must be of first quality. Paper quality both affects printing of pictures and protects well-being of the child's eyes. Matte pages that do not reflect the light should be preferred for the child's eye health. Letter size must be inversely proportional to the age of the child. In other words, the size of the letters in the book should shrink as the child grows older. Spaces, such as words and line spacings, should be left at a rate that will make it easier to read. As the age of the target group grows, ratio of visual elements in the books should also be reduced. It is important that the visuals in the books should attract the child and appeal to his/her aesthetic needs. Attention should be paid about what kind of visuals are appropriate to the content.

While choosing a tale for children, it is necessary to be careful about the content. Manner of telling must be simple and smooth. The vocabulary used should be determined according to the target group. Since rhymes can be used as an opportunity for the child to love the language, tales with lots of rhymes should be preferred. Tales with activities that will increase the interest of the child should be preferred rather than tales containing expressions such as depictions that will not attract the attention of the child for a long time. Subjects should be appropriate to the age of the child. Tales in which the main idea can be clearly articulated should be determined. Expressed themes should serve national and universal values. Tales with simple fictions should be preferred and tales should end positively. It should not be forgotten that children characters or animal characters are more attentive to the children. In order not to distort the taste of child from reality, the lecture given by the tale must be hidden in the fiction. In tales, "there should be no suggestions that lead children to numbness" (Oğuzkan, 2001: 26). There should not be any frightening elements in tales (Yardımc1 \&Tuncer, 2002: 49).

Aspects of tales that are not suitable for children do not require sacrificing educational aspects. It is necessary to treat tales with the principle of suitability to children and to benefit in terms of educational advantages (Karakuş, 2008: 31). The child needs to imagine, but terrible creatures and violent items in the tales should not affect their consciousness. (Şen, 2004: 85; Kıran, 2008: 18). Problems, conflicts, and dialogues in fairy tales should be adapted to the child's emotional, social, physical, cognitive, linguistic development and should be rearranged in the framework of suitability to children principle (Demir, 2009: 143). For example, the strong should not always be cruel, or with the awareness that poor children can also read this tale, more appropriate messages should be given to child consciousness regarding poverty and resolution.

Extraordinary elements in tales should not exceed child's imagination. In tales, real events of life must be adorned with extraordinary elements, but incidents of magic and sorcery must be avoided (Tür \&Turla, 1999: 42). Tales should end with a happy ending for children to love life and the world (Şişman, 2003: 16). It should not be ignored that dialogues in tales will constitute child's examples in terms of communication. In tales, approach to genders should be paid attention to, in terms of child psychology; the tales where women are presented weak and unequal should not be presented to children. In translated tales, in addition to language use and cultural appropriateness, care must be taken not to lose gist of tale during translation. If tales are not written in a clear style or the evil character is highlighted in tales, the child can misunderstand the lecture in the fairy tale or take evil character as example (Şişman:2003: 17). 
Bakırc1 (2004: 36-37) lists the elements to be considered tale selection as follows:

1. It should be appropriate for children's age and psychology.

2. It should be durable and printed on first quality paper.

3. Images in the book should be relevant with the subject and in vivid colors.

4. The pictures on the page should be big, and text should be less. Text characters should be adjusted according to the age of the child.

5. Short, simple, understandable phrases should be chosen.

6. Care must be taken in choosing words in terms of language development of the child.

7. Care must be taken in writing rules.

7. The child should be given love of homeland, nation, flag, family, nature, and animal.

8. Lesson to be given to the child should be spreaded throughout the text.

9. Elements including violence should be minimized.

When animal tales are used in education, it has been proved that prose tales can give more benefits for understanding than poetic tales. The reason is that, prose tales are less ornated. Prose tales are more beneficial than poetic tales in terms of memorability. Thus, the child can apply the message s/he received from the tale to his/her life for a longer time. In prose tales, the fact that canonical sentences are preponderant, makes it possible for the children to focus on the event; and the simplicity of the expression makes the lesson to be taught easily to the child. The fact that cultural items in tales are not unfamiliar to the child's culture is important in terms of the child's assimilation of tale (Onarıcioğlu, 2011: 75-76).

Pictures in the books should be appropriate to the subject. Place of the pictures on the page should match the layout of the page. Pictures should have descriptive, interpretive, entertaining features in accordance with the content. Attention should be paid to the aesthetic aspect of pictures with the consciousness that the child's aesthetic based emotions will be affected (Kayhan, 2010: 68).

The study of Arsoy (2011: 87-88) examining meanings attributed to male and female characters in tales is important in terms of showing that these approaches should be examined while they are used in education, because tales which present negative gender associations to the child should not be used in education.

The words in tales must match the age level of the child and should not contain slang words. It is important to select tale texts appropriate for child's vocabulary (Onuk: 2012: 72).

\subsection{Place of Tale in Turkish Language Education}

Language consists of listening, speaking, reading, and writing skills. Listening education starts with tales from early ages of children. In time, tale takes place in the reading education of the child with the child learning to read and write. Individual communicates by speaking and writing what he reads and listens to (Alagöz, 2002: 33).

In order to develop the skills of understanding and speaking in Turkish language lessons, the following activities with tales can be included:

* Estimating tale's subject from header and cover,

* Story telling from visuals,

* Putting themselves in place of tale heroes,

* Activities to study tale text with teaching materials (For example, with smart board and so on),

* Rhymes, reflection words, reiteratives, consolidations in tales can be used to make the students love the language,

* Tales can be read by the teacher to the students so model extensive reading can be done,

* Students can have silent reading exercises with tales, they can summarize what they read and share their work with each other,

* By repositioning event or paragraph sentences, students may be asked to reorder,

* Finding the place, time, person, main idea of the read tale with questions -answer method can be evaluated as an activity,

* True-false exercises can be done with reference to tale text,

* By drawing the attention of students to symbolic expressions in tales, composition studies can be done, 
* Stereotyped statements in tales can be taught to students for using these expressions in their own tales,

* The attention of the students can be drawn to the fiction type of tale; using this fiction in their own tale can be requested,

* New tales can be derived together with students through connotations,

* Word studies such as creating a puzzle, filling in the blanks in texts can be done according to the listened tale,

* Writing and completing a semi-finished tale can be done,

* Students can think about possibilities in a tale,

* Allowing students to write and animate dialogues about tales also improves both creativity skills and self-esteem of students (Çetinkaya, 2007: 55-58).

While tales being read address children's soul, at the same time goodness, compassion, patience, conviction, faith, tradition and customs, moral values, and similar elements must be adapted to them through the reactions of heroes to the events and the events they have experienced (İşnas, 53).

In order to ensure the spatial perception development of children, tales in which the places are consistent should be preferred. Because the child learns by comparing with close environment, places in tales should be in a style that can be compared with the environment of the child (Y1lmaz, 2010: 170).

Depictions, expressions, phrases, and rhymes in tales can be used in the name of learning the richness of the language and liking the language. Tales are a crucial tool in the sense of attaining skills such as using correct, effective, and beautiful Turkish; critical and creative thinking; communicating; problem solving; researching; entrepreneurship; reading between texts; giving importance to values that are the basis of Turkish teaching (Karakuş, 2008: 28-34)

In addition, Alptekin (2010: 178) believes that inclusion of animals in tales in Turkish textbooks will help learners to better understand speech groups such as proverbs and idioms.

Tale is a very important tool in the development of children's vocabulary in that it attracts attention of the child. The words he/she learns in this way will also become more permanent for the child (Onarıcığlu, 2011: 22).

Tales are indispensable resources in terms of giving national and universal values, when properly selected. Because Turkish Language education is also a communication skill lesson that allows people to understand and express themselves correctly, tale is a good material for the goal of educating right citizens and individuals when selected correctly.

Tales are a rich source for the child to gain abstract thinking skills. In the previous research, it is stated that poetic tales are fun for children to read and can be used to make them love reading (Onarıcıoğlu, 2011: 75-76).

İşnas (2011: 59-60) proposes activities such as asking questions based on meaning about the tale played and arranging mixed tale sections in mother tongue education activities. With these activities, it is aimed to develop listening skills. For pronunciation studies, it is stated that tales have rich vocabulary. For developping writing skills, activities such as completing semi-finished tales or changing a known tale can be applied. This will improve the child's expression skills as well as his/her ability to use vocabulary. Loud and silent tale reading exercises and animation exercises are activities that can be used for reading skills. Narration and animation of tales are among the important activities for speech skills.

Gürel et al. (2007. p. 54) summarized benefit of tales as follows:

1. As tale is one of the main types that attract children, they tend to ask questions about tales.

2. Students' speaking skills shall develop since they tell the tales they learn from others by listening.

3. The child understands the event fiction in fairy tale while listening and shall notice that he has to comply with a specific narration sequence while telling the story.

4. Tales contribute to children's vocabulary, idiom, and proverbiality information (Gürel et al., 2007: 54).

Çokakoğlu (2012: 82-83) argues that the number of books in Turkish language textbooks should be increased. He explains that there should be lots of Rhymes in these tales for drawing attention of the student. He defends the notion that tale texts should be approached with questions in terms of drawing attention. Cultural objects should take place in tales to be given to students, and these should be taught to them. Tales should be used actively in the development of listening and reading skills. Tales should be chosen so as to improve problem-solving skills of the student. Visuals about tales should also be remarkable.

\subsection{Introduce the Problem}

Since Turkish language lesson is an expression and skill lesson, it is a correct approach to provide student acquire skills 
through texts. Providing students to learn reading, speaking, writing, listening skills and linguistic rules through texts also provides the basis for permanent learning. The problem that arises here is to determine the conditions that should be considered in the selection of texts. Tales are one of the main text types students have encountered since their early ages. In this regard, fairy tales are used intensively by Turkish teachers in Turkish lessons. Elements in tales need to be examined in many respects such as their suitability for cultural transmission, psychological benefits, and harms, correct and effective use of language and so on. The opinions of the Turkish teachers in the field are very important for this subject which needs to be examined in depth. Opinions presented by Turkish teachers who have the chance to observe first responses of the students to the texts about this subject which covers many disciplines such as sociology, psychology, pedagogy, and linguistics have characteristic features of practical answers. It should not be forgotten that incorrect text selection in education will cause irreversible damages. Selecting wrong type of text as course material may lead to negative consequences such as deterioration of psychology of the student, negative attitude towards reading, student's dislike of the lesson, and misunderstanding of cultural values. In order to prevent this, it is important that the points to be considered in the selection of the text must be put into practice by teachers.

\subsection{Describe Relevant Scholarship}

According to Çetinkaya (2007: 215), a scientific criterion is needed in the selection of tales for children. The reading culture should be given to the child both at home and at school by book reading times and bookshelves.

Karakuş (2008: 35), stated in his research about tales that they emerged in the first human societies and have always been close to society. They were first created while verbal culture was dominant. They reflect culture. They take society forward. They lead to many discussions from educational point of view. They must be taken into consideration because they may contain negative aspects from educational point of view. They are important for mother tongue education.

Kiran (2008: 75) in his research states that cynical, censorious, criticizing, and accusatory expressions should not be used in tales.

Köseler (2009: 95) mentions that gender equality consciousness should be given to children and adds that works where men are shown stronger and women are shown passive create harmful consciousness in children.

Danaci (2010: 69) states that there may be differences in the name of attracting the attention of children in tales from distinct cultures, but these differences should not empty the content of tale.

Turkan (2010: 104) concluded that Keloğlan is a model tale hero and beneficial for children's cognitive and linguistic development. In reaching this conclusion, it is important that Keloğlan tales emphasize the importance of mind and adopt the language in a style close to that of the child.

İşnas (2011: 133) found that tales have positive effects on the children's conceptual development.

Arsoy (2011: 87-88) examined tales produced by verbal literature in his research and revealed how tale reflects real life beliefs with meanings attributed to the male and female characters in tales.

Altunkaynak (2012: 150-152) examined course books of primary education 1st grade in Turkish lesson in his research. He reached the findings that: The less important texts that are of significant importance for language skill. Tale images are not functional. There are language usage and punctuation mistakes in tale texts. Tale texts are printed on glossy paper which makes it difficult to read. Sturdy binding is not done. Deals with issues that are unsuitable for child psychology, such as fatalism and effortlessness. Male teachers not inclined to use tales in education as much as female teachers.

Kaplan (2012: 140), studied tales of Eflatun Cem Güney and he stated that, national spiritual values, religious values; sociological, psychological, ethical, economical, and other messages have been shown to be successful in the context of the tales text.

Firat (2012: 129), in his research, found that violence and fear elements are present in the world's children's literature products which are not written specifically for children.

Koç (2016: 60) has found that there are a lot of genuine characters in children's publications, and these publications include abstract concepts and examples of negative behavior, violence, and fear items.

\subsection{Purpose}

The aim of this study is to determine the opinions of Turkish lesson teachers teaching for $6^{\text {th }}, 7^{\text {th }}$ and $8^{\text {th }}$ grades within the scope of Turkish education for the selection of tales. For this purpose, the answers for following questions shall be searched:

1. Do the tales for children draw attention of the students?

2. Which achievements do Turkish lesson teachers use tales for? 
3. What values are most commonly attempted to be taught to students through tales?

4. Are there tales to which student give negative reactions? If so, which are they?

5. Are there any tales that students should not be taught? Why?

6. Are there tales to which student give positive reactions? If so, which are they?

7. What are the tales that should absolutelybe taught to students?

8. Can teachers create tales as teaching materials for students? Would this be different from using tales in the literature, if so what is the difference?

\section{Method}

This research's model is descriptive. Semi-structured interview is a data collection tool. Qualitative research is a method that interprets the problem with an interdisciplinary understanding (Altunış1k et al., 2010: 302). Interviewing is a powerful method of revealing the subjective expressions of people about a subjective expressions. Supporting interview process with data increases validity and reliability of the research (Yıldırım \& Şimşek, 2008: 40-41). Content analysis was done to analyse the data. Participant opinions are systematically defined with content analysis (Altunışı \& Others, 2010: 322). Before the interviews of 10 teachers who were kept out of the working group, the question "What is your opinion about the place of tales and selection of tales in Turkish education?" a 10-question interview form is prepared within the framework of answering this question. Interview form was presented to two experts in the field of Turkish Language Education in terms of scope validity. While preparing the questions, it was considered that the subject is appropriate and understandable. As a result of the opinions of experts that some questions were not related to the subject, 2 questions were drawn out from the interview form. For interview forms including 8 questions, opinions from same experts were taken again and final interview form was prepared. Thus, the researcher also prepares 8 key questions for semi-structured interview form and key questions that provide explanation of answers. Clarity of questions were tried with people in similar characteristics outside of actual interviewers.

Teachers who work in different schools are designated as participants (38 people). Number of participants is kept as wide as possible in terms of data multiplicity. Written interview forms are interpreted by giving examples from participants' opinions in the aim of research. Two expert answers are themed. Participants numbered K1, K2 etc...

Interview form questions are:

1. Do the tales draw attention of the students?

2. Which achievements do you use tales for students?

3. What values do you attempt to teach to your students through tales?

4. Are there tales to which your students give negative reactions? If so, which are they?

5. Do you think are there any tales that students should not be taught? Why?

6. Are there tales to which student give positive reactions? Please exemplify.

7. Which tales should absolutely be taught to students?

8. Can teachers create tales as teaching materials for students? Would this be different from using tales in the literature, if so what is the difference?

\section{Findings and Comments}

In the context of the research, the following table comes out when teacher responses for the question "Do the tales draw attention of the students?" are themed:

Table 1. Distribution of answers to first questions of the interview form

\begin{tabular}{llll}
\hline Question 1 answers & Participants & f & $\%$ \\
\hline Attractive & $\mathrm{K} 1, \mathrm{~K} 2, \mathrm{~K} 3, \mathrm{~K} 4, \mathrm{~K} 5, \mathrm{~K} 6, \mathrm{~K} 7, \quad 37$ & \\
& $\mathrm{~K} 8, \mathrm{~K} 9, \mathrm{~K} 10, \mathrm{~K} 11, \mathrm{~K} 12, \mathrm{~K} 13$, & \\
$\mathrm{K} 14, \mathrm{~K} 15, \mathrm{~K} 16, \mathrm{~K} 17, \mathrm{~K} 18$, & \\
$\mathrm{K} 19, \mathrm{~K} 20, \mathrm{~K} 21, \mathrm{~K} 22, \mathrm{~K} 23$, & \\
& $\mathrm{K} 24, \mathrm{~K} 25, \mathrm{~K} 26, \mathrm{~K} 27, \mathrm{~K} 28$, & \\
& $\mathrm{K} 29, \mathrm{~K} 30, \mathrm{~K} 31, \mathrm{~K} 32, \mathrm{~K} 33$, & \\
K34, K35, K36, K37 & 1 & $\% 2.63$ \\
\hline
\end{tabular}

When Table 1 is examined, participants except one seem to have found tales interesting for all students. 
Sample participant statements are as follows:

Sample participant statements appropriate for "attractive" theme:

K8: "Tales draw more attention of students than other text types."

K23: "Tales draw attention of and are more appreciated by $5^{\text {th }}$ and $6^{\text {th }}$ graders at class level. Even if not at the same rate, $7^{\text {th }}$ and $8^{\text {th }}$ graders are also interested in tales.

Sample participant statements appropriate for "sometimes" theme are as follows:

K13: "Sometimes."

In the context of the research, the following table comes out when teacher responses for the question "Which achievements do you use tales for students? are themed:

Table 2. Distribution of answers to second questions of the interview form

\begin{tabular}{|c|c|c|c|}
\hline Question 2 answers & Participants & $\mathrm{f}$ & $\%$ \\
\hline Text type & K1, K3, K6 & 3 & $\% 7.8$ \\
\hline Listening & K4, K11, K29 & 3 & $\% 7.8$ \\
\hline Understanding information & $\begin{array}{l}\text { K1, K3, K5, K6, K12, K15, } \\
\text { K17, K19, K21, K23, K25, } \\
\text { K28, K29, K36, K37 }\end{array}$ & 15 & $\% 39.4$ \\
\hline Moral values & $\begin{array}{l}\text { K2, K9, K12, K13, K14, K16, } \\
\text { K20, K22, K26, K27, K30, } \\
\text { K31, K35 }\end{array}$ & 13 & $\% 34.2$ \\
\hline Language skills & $\begin{array}{l}\text { K7, K8, K10, K12, K24, K26, } \\
\text { K29, K30, K32, K33, K34 }\end{array}$ & 11 & $\% 28.9$ \\
\hline Visual reading & K3 & 1 & $\% 2.6$ \\
\hline Description & K18 & 1 & $\% 2.6$ \\
\hline Imagination & K22 & 1 & $\% 2.6$ \\
\hline Reality-fiction difference & K6, K17, K24 & 3 & $\% 7.8$ \\
\hline
\end{tabular}

When Table 2 is examined, it is seen that teachers use tales primarily for semantic knowledge and moral values, and then for language skills achievements.

Since the same participant can refer to more than one theme in this question, participant sample sentences are not separated into themes. Sample participant statements are as follows:

K3: “*Predicts the content of tale from visuals.

*Looks for answers of $5 \mathrm{~W} 1 \mathrm{H}$ questions after listening and reading.

*Visualizes listened and read material in mind.

*Determines extraordinary events and characters in tale.

*Recognizes form and content characteristics that separate tales from other types.

*Determines the characteristics of tale by going from part to whole"

K4: "I read tales while having students comprehend listening rules. They focus their attention on tale."

K6: "Students determine subject and main idea of what they read. Distinguishes between truth and fiction. Determines type of read text."

K7: "Reading and writing, especially listening and speaking."

K8: "For achievements of listening and speaking."

K12: "I use (them) in reading, understanding, speaking, and self-expression fields. I use in terms of imagination development for helping them understand what they read, for building empathy, for making them understand helpfulness."

K22: "For helping them take lessons, giving advice and developing their imaginary world."

In the context of the research, the following table comes out when teacher responses for the question "Which values do you attempt to teach to your students through tales?" are themed: 
Table 3. Distribution of answers to third questions of the interview form

\begin{tabular}{|c|c|c|c|}
\hline Question 3 answers & Participants & $\mathrm{f}$ & $\%$ \\
\hline Values education & $\begin{array}{l}\text { K1, K5, K6, K7, K12, K13, } \\
\text { K14, K18, K19, K20, K21, } \\
\text { K25, K26, K27, K28, K30, } \\
\text { K36 }\end{array}$ & 17 & $\% 44.7$ \\
\hline Generosity & $\mathrm{K} 22$ & 1 & $\% 2.6$ \\
\hline Goodness & $\begin{array}{l}\text { K2, K3, K4, K5, K8, K10, } \\
\text { K11, K15, K16, K17, K23, } \\
\text { K25, K35, K37 }\end{array}$ & 14 & $\% 36.8$ \\
\hline Honesty & $\begin{array}{l}\text { K2, K9, K11, K15, K17, K22, } \\
\text { K25, K31, K35 }\end{array}$ & 9 & $\% 23.6$ \\
\hline Love & $\begin{array}{l}\text { K2, K8, K24, K29, K31, K32, } \\
\text { K37 }\end{array}$ & 7 & $\% 18.4$ \\
\hline Respect & $\begin{array}{l}\text { K2, K8, K10, K11, K24, K31, } \\
\text { K32, K33, K34 }\end{array}$ & 9 & $\% 23.6$ \\
\hline Helpfulness & $\mathrm{K} 4, \mathrm{~K} 25, \mathrm{~K} 34$ & 3 & $\% 7.8$ \\
\hline Courage & K15 & 1 & $\% 2.6$ \\
\hline Empathy & K11 & 1 & $\% 2.6$ \\
\hline Sharing & K25 & 1 & $\% 2.6$ \\
\hline Fairness & $\mathrm{K} 10, \mathrm{~K} 15, \mathrm{~K} 24, \mathrm{~K} 29, \mathrm{~K} 32$ & 5 & $\% 13.15$ \\
\hline Peace & $\mathrm{K} 8, \mathrm{~K} 25$ & 2 & $\% 5.26$ \\
\hline Friendship & K8, K33, K34 & 3 & $\% 7.8$ \\
\hline Diligence & K9, K22, K35 & 3 & $\% 7.8$ \\
\hline Responsibility & K31 & 1 & $\% 2.6$ \\
\hline
\end{tabular}

When Table 3 is examined, it can be seen that teachers use tales as teaching materials to teach values to students. Teachers often respond to this question as values education in general sense, this response is followed by goodness, honesty, respect, and love answers.

Since the same participant can refer to more than one theme in this question, participant sample sentences are not separated into themes. Sample participant statements are as follows:

K3: "One of the most prominent features of tales is that good people win, and bad people are punished somehow. From this point, I convey to my students all values that will contribute to their being good people taking into account the subject of tale. Thus, in our work which is education and teaching, we are not only focused on teaching."

K7: "Tales play a significant role in the transfer of cultural values. The child learns his/her own culture. In addition, general moral values, and universal values (goodness, honesty, cooperation, friendship ...) are instilled in the child.

K19: "I am trying to teach national culture elements."

In the context of the research, the following table comes out when teacher responses for the question "Are there tales to which your students give negative reactions? If so, which are they?" are themed:

Table 4. Distribution of answers to fourth questions of the interview form

\begin{tabular}{llll}
\hline Question 4 answers & Participants & f & $\% 21.05$ \\
\hline Extraordinary elements & K1, K3, K9, K11, K12, K13, 8 & \\
& K26, K35 & & $\% 42.10$ \\
No & K2, K5, K7, K8, K10, K15, & 16 & \\
& K16, K18, K19, K20, K22, & & $\% 5.26$ \\
Reaction to hero & K23, K30, K31, K32, K33 & 2 & $\% 2.6$ \\
Bad end & K4, K6 & 1 & $\% 10.52$ \\
Contrary to values & K24, K27, K28, K29 & 4 & $\% 5.26$ \\
Violence & K21, K36 & 2 & $\% 2.6$ \\
Uninteresting & K25 & 1 & \\
\hline
\end{tabular}

When Table 4 is examined, there may be an interpretation that teachers often do not encounter situations where students generally look askance at tales. This is followed by an answer that students react negatively to extraordinary events.

Sample participant statements according to themes are as follows:

Sample participant statements for extraordinary elements are as follows:

K3: "It is not a negative reaction, but sometimes tales are seen absurd for some of our students. They use sentences like 
“'Such a thing never happens, it cannot be real.' When I tell that this is the characteristic of tales, the objections are gone. My students are persuaded."

K9: "This sometimes happens. In Seven-Husband Giant tale, they criticize marriage of seven times. Children do not see what is described as a metaphor because they cannot embody it. Therefore, they exclude what they do not understand."

K12: "They give reaction to exaggerated, fantastic tales. It sounds strange because they compare it to the real world."

Sample participant statements about reaction to hero theme are as follows:

K4: "Students can give reaction to some tales. 'If I were in hero's position, I could have acted in opposite way. I would do evil, against evil.

K6: "It happens. Students with a tendency to violence say that if the problem is told, the solution will be violence."

Sample participant statements about "contrary to values" theme include the following:

K24: "They react to tales that do not match their values and in which evils win."

K27: "There are negative reactions in terms of perceiving and interpreting cultural values and getting used to roles in tales."

K29: "They give reactions to tales which are incompatible with their own values."

Sample participant statements for bad end theme are:

K14: "Yes, to unhappy tales and to tales ending with death. Because the perception is that tale always ends with a happy ending."

Sample participant statements for violence theme are:

K21: "Tales which include unsuitable content cause negative reactions."

K36: "Some exaggerated violence in publications of some tales cause children to be negatively affected in this direction. Children cannot perceive these tales, react negatively and show wrong behaviours because they cannot fully understand the message."

Sample participant statements for uninteresting theme are:

K25: "Certainly happens; these types of tales are more or less uninteresting."

In the context of the research, the following table comes out when teacher responses for the question "Are there any tales that students should not be taught? If so, why?" are themed:

Table 5. Distribution of answers to fifth questions of the interview form

\begin{tabular}{llll}
\hline Question 5 answers & Participants & f & $\%$ \\
\hline No & K1, K2, K3, K4, K6, K8, K10, 17 & $\% 44.7$ \\
& K11, K12, K14, K15, K19, & & \\
K22, K24, K30, K31, K32 & & $\% 26.31$ \\
Negative content & K9, K21, K23, K25, K28, 10 & $\% 2.6$ \\
& K34, K33, K35, K36, & & $\% 7.8$ \\
Spiritless & K13 & 1 & 3 \\
Contrast of values & K26, K29, K37 & 3
\end{tabular}

When Table 5 is examined, it is seen that teachers are leading the opinion that there is not a fairy tale that should not be read. This answer is followed by the response that tales with negative contents should not be read.

Sample participant statements according to themes are:

Sample participant statements for "No" theme are:

K3: "I think there's no fairy tale that should not be taught. Sometimes we act sensitively and think "can the child be negatively affected?" But I think it's okay to teach, if these negativities of types which can be encountered in life."

K19: "No. Because the effect of tales on understanding and comprehension is strong."

K32: "They should read every tale whether it is good or bad. So, they can know what is good and what is bad."

Sample participant statements for "Negative content" theme are:

K9: "For example, it is tragic that daughter dies at the end of Little Match Girl tale. This effects psychology of the child negatively."

K23: "I think that tales which have elements of violence and do not bring good values to the foreground should not be taught." 
K35: "Some tales from world classics are not appropriate. Characters like Giant and witch can harm student's personal development."

K36: "Care should be taken since traditional tales have very heavy content."

Sample participant statements for "Spiritless" theme are:

K13: "Tales without soul hould not be taught."

Sample participant statements for "Contrast of values" theme are:

K26: "Yes, there may be tales which are not effective for giving values."

K29: "They should not read tales which are higher than their level of values, and which are not appropriate to their values.

In the context of the research, the following table comes out when teacher responses for the question "Are there tales to which student give positive reactions? If so, which are they?" are themed:

Table 6. Distribution of answers to sixth questions of the interview form

\begin{tabular}{|c|c|c|c|}
\hline Question 6 answers & Participants & $\mathrm{f}$ & $\%$ \\
\hline No & $\mathrm{K} 1, \mathrm{~K} 7, \mathrm{~K} 31$ & 3 & $\% 7.8$ \\
\hline Keloğlan & $\begin{array}{l}\text { K2, K4, K5, K6, K7, K12, } \\
\text { K15, K16, K23 }\end{array}$ & 9 & $\% 23.6$ \\
\hline Cinderella & $\mathrm{K} 23$ & 1 & $\% 2.6$ \\
\hline Andersen Tales & $\mathrm{K} 3$ & 1 & $\% 2.6$ \\
\hline $\begin{array}{l}\text { One Thousand and One } \\
\text { Nights Tales }\end{array}$ & K20 & 1 & $\% 2.6$ \\
\hline Kelile and Dimne & K5, K34 & 2 & $\% 5.26$ \\
\hline Grimm Brothers & $\mathrm{K} 20$ & 1 & $\% 2.6$ \\
\hline Snow White & $\mathrm{K} 5, \mathrm{~K} 9, \mathrm{~K} 16, \mathrm{~K} 23$ & 4 & $\% 10.52$ \\
\hline Aesop & $\mathrm{K} 6, \mathrm{~K} 7, \mathrm{~K} 8$ & 3 & $\% 7.8$ \\
\hline Pinocchio & K6 & 1 & $\% 2.6$ \\
\hline Crystal Pavillion & K7 & 1 & $\% 2.6$ \\
\hline La Fontaine & K7 & 1 & $\% 2.6$ \\
\hline Adventurous Content & K19, K29, K30 & 3 & $\% 7.8$ \\
\hline Cem Eflatun Güney & K7 & 1 & $\% 2.6$ \\
\hline All & $\mathrm{K} 10, \mathrm{~K} 16$ & 2 & $\% 5.26$ \\
\hline Samed Bahrengi & K11 & 1 & $\% 2.6$ \\
\hline About their lives & $\mathrm{K} 13, \mathrm{~K} 29, \mathrm{~K} 30, \mathrm{~K} 32$ & 4 & $\% 10.52$ \\
\hline All with happy end & $\begin{array}{llll}\text { K14, } & \text { K22, } & \text { K24, } & \text { K25, } \\
\text { K27, } 26, \\
\text { K328, }\end{array}$ & 12 & $\% 31.57$ \\
\hline
\end{tabular}

When Table 6 is examined, ranking of tales of most positive reactions given by students can be done respectively as: all tales which have a happy ending, Keloğlan tales, Snow white tales, Aesop's Fables, and adventure tales, Kelile and Dimne, Cinderella, Andersen and One Thousand and One Nights, Grimm Brothers Tales, Crystal Pavilion Tales, La Fontaine Fables, Cem Eflatun Güney Tales, and Samed Bahrengi tales. Three of the teachers had the opinion that the students did not react positively to all tales, and two of them had the opinion that all students reacted positively to all tales.

Since the same participant also gives answers that can fit in different themes, participant sample sentences are given in general:

K5: "Keloğlan, Snow White, Kelile and Dimne"

K6: "Keloğlan Tales, Pinocchio, Aesop tales"

K7: "Crystal Pavillion tales, Aesop Tales, La Fontaine tales, Keloğlan tales, books of Cem Eflatun Güney tales"

K9: "For example, it is tragic that daughter dies at the end of Little Match Girl tale. This effects psychology of the child negatively."

K20: "For example, One Thousand and One Nights Tales and Grimm Brothers tales can be taught. Universal values are commonly seen in these tales."

K29: "Tales with heroes like him, funny tales, tales causing wonder..."

K30: "They react positively when they connect to daily life. Adventure tales, which takes you to right from wrong develop emotional skills. 
In the context of the research, the following table comes out when teacher responses for the question "What are the tales that should absolutely be taught to students?" are themed:

Table 7. Distribution of answers to seventh questions of the interview form

\begin{tabular}{|c|c|c|c|}
\hline Question 7 answers & Participants & $\mathrm{f}$ & $\%$ \\
\hline Aesop Tales & $\mathrm{K} 1, \mathrm{~K} 2, \mathrm{~K} 3, \mathrm{~K} 12, \mathrm{~K} 15$ & 5 & $\% 13.15$ \\
\hline Keloğlan & $\begin{array}{l}\mathrm{K} 2, \mathrm{~K} 3, \mathrm{~K} 10, \mathrm{~K} 12, \mathrm{~K} 14, \mathrm{~K} 15, \\
\mathrm{~K} 23, \mathrm{~K} 24, \mathrm{~K} 25, \mathrm{~K} 26, \mathrm{~K} 29, \\
\mathrm{~K} 36\end{array}$ & 12 & $\% 31.57$ \\
\hline Turkish tales & $\mathrm{K} 1, \mathrm{~K} 5, \mathrm{~K} 19, \mathrm{~K} 34$ & 4 & $\% 10.52$ \\
\hline World tales & K19, K27, K34 & 3 & $\% 7.8$ \\
\hline Andersen Tales & $\mathrm{K} 3, \mathrm{~K} 12, \mathrm{~K} 26, \mathrm{~K} 32, \mathrm{~K} 36$ & 5 & $\% 13.15$ \\
\hline Dada Gorgud & $\mathrm{K} 23$ & 1 & $\% 2.6$ \\
\hline Values education & K4, K6, K28, K30, K33 & 5 & $\% 13.15$ \\
\hline $\begin{array}{l}\text { One Thousand and One } \\
\text { Nights Tales }\end{array}$ & $\begin{array}{l}\text { K3， K24， K25， K26， K32, } \\
\text { K36 }\end{array}$ & 6 & $\% 15.78$ \\
\hline Ali Baba and Forty Thieves & $\mathrm{K} 3$ & 1 & $\% 2.6$ \\
\hline Hansel and Gratel & $\mathrm{K} 3$ & 1 & $\% 2.6$ \\
\hline The Pied Piper of Hamelin & K3 & 1 & $\% 2.6$ \\
\hline Ugly Duck & K17 & 1 & $\% 2.6$ \\
\hline Tom Thumb & K17 & 1 & $\% 2.6$ \\
\hline $\begin{array}{l}\text { The Ant and The } \\
\text { Grasshopper }\end{array}$ & K35 & 1 & $\% 2.6$ \\
\hline Little Black Fish & $\mathrm{K} 7, \mathrm{~K} 11$ & 2 & $\% 5.26$ \\
\hline Cinderella & K9 & 1 & $\% 2.6$ \\
\hline Rapunzel & K10 & 1 & $\% 2.6$ \\
\hline All & K31 & 1 & $\% 2.6$ \\
\hline Nasreddin Hodja & $\mathrm{K} 10, \mathrm{~K} 14$ & 2 & $\% 5.26$ \\
\hline $\begin{array}{l}\text { One Peach and a Thousand } \\
\text { Peaches }\end{array}$ & K11 & 1 & $\% 2.6$ \\
\hline Abu Hasan and the Fart & K11 & 1 & $\% 2.6$ \\
\hline La Fontaine & $\mathrm{K} 29, \mathrm{~K} 15, \mathrm{~K} 25$ & 3 & $\% 7.8$ \\
\hline Grimm Brothers & $\begin{array}{l}\text { K20，K24，K25，K26，K32， } \\
\text { K36 }\end{array}$ & 6 & $\% 15.78$ \\
\hline Most & $\mathrm{K} 16, \mathrm{~K} 37$ & 2 & $\% 5.26$ \\
\hline Little Prince & $\mathrm{K} 22$ & 1 & $\% 2.6$ \\
\hline
\end{tabular}

When Table 7 is examined, according to the teachers, tales which should be absolutely read by students are listed as follows: Keloğlan, Grimm Brothers, One Thousand and One Nights, Aesop's Fables and Andersen Tales and tales for values education, Turkish Tales, World Tales and especially La Fontaine Fables, Little Black Fish, Nasreddin Hodja tales, Dada Gorgud Tales, Ali Baba and Forty Thieves, Hansel and Gratel, The Pied Piper of Hamelin, Ugly Duck, Tom Thumb, The Ant and The Grasshopper, Cinderella, Rapunzel, One Peach and a Thousand Peaches, Abu Hasan and the Fart, Little Prince. Two of the teachers support that the majority of tales should be read.

Since the same participant also gives answers that can fit in different themes, participant sample sentences are given in general:

K3: "I think not only tales; all classical works add more to the reader in general. So I think it is important not only to read, but to read quality. In this context, we should start with the classical works which we grew up and I think that these works should be taught absolutely. Namely One Thousand and One Nights Tales, Keloğlan Tales, Ali Baba and Forty Thieves, Hansel and Gratel, The Pied Piper of Hamelin... and more which I could not write the name of, must be taught at appropriate age and level, should not be out of an event when the student hears something about these books somewhere they should participate. "

K4: "Tales of values education should be taught."

K9: "Cinderella must be taught because good-hearted people will soon reach the values they deserve."

K23: "Keloğlan Tales and Dada Gorgud tales should definitely be taught in terms of transmission of national culture and values.

In the context of the research, the following table comes out when teacher responses for the questions "Can teachers create tales as teaching materials for students? Would this be different from using tales in the literature, if so what is the difference?" are themed: 
Table 8. Distribution of answers to eight questions of the interview form

\begin{tabular}{llll}
\hline Question 8 answers & Participants & f & $\%$ \\
\hline They must write & K6, K7, K8, K11, K16, K19, & 10 & $\% 26.31$ \\
& K20, K25, K27, K30 & & $\% 7.8$ \\
Up to date & K1, K2, K14 & 3 & $\% 21.05$ \\
They must not write & K15, K23, K26, K31, K32, & 8 & $\% 13.15$ \\
& K34, K36, K37 & & $\% 10.52$ \\
Suitability to target audience & K3, K9, K12, K13, K28 & 5 & $\% 2.6$ \\
Suitability to achievements & K4, K22, K33, K35 & 4 & $\% 2.6$ \\
No difference & K21 & 1 & $\% 7.8$ \\
Difference & K5 & 1 & 3 \\
Kore interest & K10, K18, K29 & 3 & \\
\hline
\end{tabular}

When Table 8 is examined, about writing a fairy tale as an educational material, 10 of the teachers think that they should write, while 8 of them think that they should not write. There are also those who think that it will be better, and teachers should write tales in terms of suitability to target group, achievements and actuality.

Sample participant statements according to the themes are:

Sample participant statements for "They must write" theme are:

K11: "Can be created."

K16: "Can be created."

Sample participant statements for "Actual" theme are:

K1: "Yes if he/she has the ability; it would be better if it is up to date."

K14: "Trendier, the innovations that reflect changes of the times would be in tale."

Sample participant statements for "They must not write" theme are:

K15: "Teachers can also create, but there can be some troubles. Using tales in the literature is more effective."

K23: "They may create, but it is necessary that people who do this should be experts in their field and the created tales must be inspected. They may be more ineffective and passive than tales in the literature."

K26: "Teachers may create. Those would be different than existing tales. This situation will change according to the equipment, character, education, perception, experience, and information of the teacher."

K31: "I am in favor of using tales in the literature. Because they were prepared professionally considering the subject, scope, and age. The values to be gained are more varied. Teachers' tales may not iclude enough values. There is a possibility that they may give incorrect message to students."

K34: "This is a job that requires rigor. Teachers can create a tale by paying attention to some rules. Tales in the literature are more sophisticated and found more interesting by students since they are formed by culture accumulation and common property of the society. If teacher prepares good (tales), students may enjoy it."

Sample participant statements for "Suitability to target audience" theme are:

K3: "Tales can be created by teachers. In general, although not so different, it can have the following advantages: Tales prepared according to the social presence of the student can be more remarkable. For example, the event can happen in neighborhood, and character can be from their close environment. I think perception will become even more open this way. In fact, students love to animate tale in the class."

K12: "(They) can be created. That would be good, too. It is more interesting to read and listen to familiar events and people around. They will find traces of their own (experiences?). They would read it in pleasure."

Sample participant statements for "Suitability to achievements" theme are:

K4: "Teachers can also create tales. They can write to tell the behavior they want to bring to their classes in a tale."

K22: "Yes they may create. Yes this would be different. The difference may be especially in terms of values students gain."

Sample participant statements for "No difference" theme are:

K21: "New tales can be created. He can give something he wants to teach through tales. Not much difference."

Sample participant statements for "Difference" theme are:

K5: "It may be appropriate in terms of difference." 
Sample participant statements for "More interest" theme are:

K18: "It would be different, and get more attention."

K10: "New Talescan be created. Teachers can also create a tale by following general characteristics of tales and using their imagination. Students may be more interested in the tales that teachers create."

\section{Discussion and Results}

Similar to findings of this research, according to Çetinkaya (2007: 2015), a scientific criterion is needed in selecting fairy tales for children. In his research (2008: 35), Karakuş also notes that tales must be examined because they may contain negative aspects in terms of education. In this respect, Karakuş's view supports the purpose of the study. Kiran (2008: 75) supports the findings of this study by arguing that there should not be sarcastic statements in tales. Köseler (2009: 95) supports the findings of this study by advocating that gender equality consciousness should be taught to children. Danac1 (2010: 69) contributes to this study by stating that changes because of the translation should not cause tale to lose its characteristics. As can be seen in the findings of this research, Türkan (2010: 104) also finds Keloğlan tales useful for children in many ways. İşnas (2011: 133) is among those who advocate that tales contribute to children's conceptual development. Altunkaynak (2012: 150-152) has included features that should be found in tales in textbooks in his own study matching with findings of this study. Kaplan (2012: 140), refers to the importance of value education in tales as mentioned in this study. Firat (2012: 129) and Koç (2016: 60) also point out that there should be no violence-fear items in tales, as we have pointed out in this study.

As a result of this research, the following conclusions can be drawn:

Participants except one seem to have found tales interesting for all students. It is seen that teachers use talents primarily for semantic knowledge and moral values, and then for language skills achievements. Teachers have answers that they use tales more for values such as goodness, honesty, respect, and love. There may be an interpretation that teachers often do not encounter situations where students generally look askance at tales. This is followed by an answer that students react negatively to extraordinary events. It is seen that teachers are leading the opinion that there is not a fairy tale that should not be read. This answer is followed by the response that tales with negative contents should not be read. Ranking of tales of most positive reactions given by students can be done respectively as: all tales which have a happy ending, Keloğlan tales, Snow white tales, Aesop's Fables, and adventure tales, Kelile and Dimne, Cinderella, Andersen and One Thousand and One Nights, Grimm Brothers Tales, Crystal Pavillion Tales, La Fontaine Fables, Cem Eflatun Güney Tales, Samed Bahrengi tales. Three of the teachers had the opinion that the students did not react positively to all tales, and two of them had the opinion that all students reacted positively to all tales. According to teachers, tales which should be absolutely read by students are listed as follows: Keloğlan, Grimm Brothers, One Thousand and One Nights, Aesop's Fables and Andersen Tales and tales for values education, Turkish Tales, World Tales and especially La Fontaine Fables, Little Black Fish, Nasreddin Hodja tales, Dada Gorgud Tales, Ali Baba and Forty Thieves, Hansel and Gratel, The Pied Piper Of Hamelin, Ugly Duck, Tom Thumb, The Ant and The Grasshopper, Cinderella, Rapunzel, One Peach and a Thousand Peaches, Abu Hasan and the Fart, Little Prince. Two of the teachers support that the majority of tales should be read. About writing a fairy tale as an educational material, 10 of the teachers think that they should write, while 8 of them think that they should not write. There are also those, who think that it will be better, and teachers should write tales in terms of suitability to target group and achievements and actuality.

Tale type, which can be used in terms of values education, language skills and many achievements is a type that should not be neglected for Turkish Education. Teachers should take this into consideration in the texts they give to their students by taking advantage of this work and similar works that reveal which parts of tales should be read and which type of tales should be avoided. It is important to increase the number of studies that show why and how tales should be used as teaching materials in Turkish Lessons and to ensure that Turkish teachers follow these studies.

\section{References}

Alagöz, F. C. (2012). Contribution of basic values to Turkish education in tales books of Cahit Uçuk. Master Thesis, Institute of Social Sciences, Uşak University, Uşak.

Altunisik, R., Coskun, R., Bayraktaroglu, S., \& Yildirim, E. (2010). Research methods in social sciences, SPSS applied. İstanbul: Sakarya Publishing. ISBN, 1759261797.

Altunkaynak, M. (2012). Teachers' opinions about usage of texts in fairy tales in primary school 1st level Turkish language textbooks. Master's Thesis, Çukurova University, Institute of Social Sciences, Adana.

Arsoy, N. (2011). Patriarchy, gender discrimination and women in Turkish tales. Master's Thesis, Kafkas University, Institute of Social Sciences, Kars.

Bakı1, N. (2004). An examination on animal tales determined in Turkish geography, Konya, 36-37. 
Boratav, P. N. (1995). Turkish Folk Literature in 100 questions. İstanbul: Gerçek Yayınevi.

Çetinkaya, Z. (2007). The importance of tales in teaching Turkish, Unpublished PhD Thesis, Dokuz Eylül University Educational Sciences Institute, İzmir.

Çokakoğlu, O. (2012). According to 2006 program, utilization of fairy tale texts in 6. 7. 8th grade Turkish textbooks, Master's Thesis, Çanakkale Onsekiz Mart University, Institute of Educational Sciences, Çanakkale.

Danac1, F. E. (2010). Translations of Little Red Riding Hood tale in terms of the role of intercultural interaction, Master's Thesis, Yildiz Technical University, Institute of Social Sciences, İstanbul.

Demir, Y. O. (2009). Interpersonal conflict resolution process in children's fairy tales. Master's Thesis, Ankara University, Institute of Educational Sciences, Ankara.

Dilidüzgün, S. (2003). Tales in child development process. Anadili Magazine Special Issue about Tale Issue 31, 10-15.

Firat, H. (2012). Examination of fairy tale and story books prepared for preschool children in terms of fear and violence. Master's Thesis, Çanakkale Onsekiz Mart University, Institute of Educational Sciences, Çanakkale.

Günay, U. (1975). Elazığ tales. Erzurum: Atatürk University Press.

Gürel, Z., Temizyürek, F., \& Şahbaz, N. K. (2007). Children's literature. Ankara: Öncü Kitap (Pioneering Book).

İşnas, S. (2011). A study on the effect of fairy tale on child's concept development, Cahit Zarifoğlu's Example, Unpublished Master's Thesis, Afyon Kocatepe University Social Sciences Institute.

Kaplan, O. (2012). Examination of tales written and edited by Eflatun Cem Güney in terms of character education in children. Master's Thesis, Institute of Social Sciences, Fatih University, İstanbul.

Karakuş, E. (2008). Tales from the point of development of social skills in primary education 2nd level Turkish language teaching, Master's Thesis, Karaelmas University, Institute of Social Sciences, Zonguldak.

Karatay, H. (2007). The importance and function of the fairy tale in the process of value acquisition and language acquisition. Journal of Turkish Educational Sciences, 3, 463-477.

Kayhan, Z. T. (2010). Illustrative and typographic balance in fairy tale books taught to primary school students in the first grade and analysis of 5 selected fairy tales. Master's Thesis, Gazi University, Institute of Educational Sciences, Ankara.

Kayman, F. (2011). Examination of tales in Bingöl in terms of child education. Master Thesis, Yüzüncü Yıll University, Institute of Social Sciences, Van.

Kıran, S. (2008). Communication obstacles in tale books and story books prepared for preschool children, Adnan Menderes University, Institute of Social Sciences, Aydın.

Koç, Z. (2016). The positive and negative effects of fairy tales on the development of pre-school children in 5th and 6th age groups. Master's Thesis, İstanbul Aydın University, Institute of Social Sciences, İstanbul.

Köseler, F. (2009). Gender Case in Pre-school Story and Tale Books, Master Thesis, Adnan Menderes University, Institute of Social Sciences, Aydın.

Oğuzkan, F. (2001). Children's Literature. Ankara: Anı Yayınları.

Onarıcıoğlu, A. S. (2011). The effect of verse animal tales on understanding and remembering skills. Master's Thesis, Selçuk University, Institute of Educational Sciences, Konya.

Onuk, E. Ö. (2012). Adequacy of vocabulary of tales taught in pre-school institutions of Adapazarı Merkez town to the level of 6 year old children (Sakarya example). Master's Thesis, Sakarya University Institute of Educational Sciences.

Sakaoğlu, S. (1999). Fairy Tale Researches. Akçağ.

Sakaoglu, S. (1999). Tale researches. Ankara: Akçağ Yayınları.

Şen, S. (2004). Examination of story and tale books in terms of effects on language and concept development of preschool children, project study: Aydın.

Şişman, B. (2003). Using tales for education and orientation of children, Ondokuz Mayls University Faculty of Education Journal, I.15, 11-17.

Tezel, N. (1987). Turkish tales, Children's Literature Yearbook. İstanbul: Gökyüzü Yayınları, 134-144.

Tür, G., \& Turla, A. (1999). Child, literature, and book in preschool, Ya-Pa Press: İstanbul 
Türkan, F. T. (2010). Examination of the Keloğlan tales in terms of cognitive development (6-12 years), Master's Thesis, Gazi University, Institute of Educational Sciences, Ankara.

Ünlüer, P. (2013). Examination of tales in terms of religious and moral values (Crystal Pavillion Tales Example). Master's Thesis, Institute of Social Sciences, Marmara University, İstanbul.

Yalçın, A., \& Aytaş, G. (2003). Children’s literature. Ankara: Akçağ Yayınları.

Yalçın, A., \& Giyasettin, A. (2002). Children's literature. Ankara: Akçăg.

Yardımc1, M. (1996). Living Malatya tales. Malatya: İnönü Üniversitesi Yayınları.

Yardımc1, M. (2004). Prose in Turkish folk literature. Ankara: Ürün Yayınları.

Yardımc1, M., \& Tuncer, H. (2002). Children's literature for education faculties. İzmir: Ürün Yayınları

Yildirim, A., \& Simsek, H. (2008). Qualitative research methods. Ankara: Seçkin Yayınevi.

Yilmaz, G. (2010). The influence of fairy tales on the development of spatial perception in child, Master's Thesis, Dokuz Eylül University, Institute of Science and Technology, İzmir.

\section{Copyrights}

Copyright for this article is retained by the author(s), with first publication rights granted to the journal.

This is an open-access article distributed under the terms and conditions of the Creative Commons Attribution license which permits unrestricted use, distribution, and reproduction in any medium, provided the original work is properly cited. 